\title{
FISH AS A POTENTIAL SOURCE OF COLLAGENOLYTIC AND FIBRINOLYTIC ENZYMES OF INTEREST TO THE PHARMACEUTICAL AND BIOMEDICAL INDUSTRY.
}

\author{
V. M. OLIVEIRA ${ }^{1}, \underline{\text { C. H. RODRIGUES }}{ }^{2}$, T. P. NASCIMENTO ${ }^{3}$, A. L. F. PORTO ${ }^{1,3}$. \\ ${ }^{1}$ Universidade Federal Rural de Pernambuco, Departamento de Morfologia e Fisiologia \\ Animal \\ ${ }^{2}$ Universidade Federal de Pernambuco, Departamento de Ciências Farmacêuticas \\ ${ }^{3}$ Laboratório de Imunopatologia Keizo Asami (LIKA), Universidade Federal de Pernambuco \\ claudiohrodrigues@live.com
}

\begin{abstract}
Neglected fish processing wastes are promising sources of biomolecules with potential for industrial application. This work aimed to perform a sorting of discarded fish residues (Rachycentron canadum, Caranx crysos, Lutjanus synagris, Scomberomorus mackerel, Parachromis managuensis, Colossoma macropomum, Oreochromis niloticus, Pseudoplatystoma corruscans, Cichla ocellaris, Cynoscion leiarchus) and shrimp hydrolyzate (Litopenaeus vannamei) investigating the presence of collagenolytic and fibrinolytic enzymes. The collagenolytic activities varied according to the species, between $15.95 \pm 0.07$ U/mg (P. corruscans) and $94.35 \pm 0.02 \mathrm{U} / \mathrm{mg}$ (C. ocellaris). After sorting by collagenolytic activity, the species selected was Cichla ocellaris, having the biochemical properties defined. Optimal $\mathrm{pH}$ and temperature of collagenolytic activity were 7.5 and $55^{\circ} \mathrm{C}$, respectively, showing stability at pH range from 6.5 to 11.5 and temperatures ranging from 25 to $60^{\circ} \mathrm{C}$. The enzyme was sensitive to $\mathrm{Cu}^{2+}, \mathrm{Hg}^{2+}$ and $\mathrm{Pb}^{2+}$, being partially inhibited by PMSF, TLCK and Benzamidine. The fibrinolytic activities varied between $5.51 \pm 0.02$ and $56.16 \pm 0.42 \mathrm{U} / \mathrm{ml}$, indicating another possibility of reuse of these byproducts. The results suggest intestinal fish viscera as a promising source of collagenolytic enzymes and shrimp hydrolyzate as well as fibrinolytic, both of which have palpitations in the pharmaceutical and biomedical industry after purification processes.
\end{abstract}

Key words: Collagenolytic, Fibrinolytic, Fish.

RESUMO - Os resíduos de processamento de peixes negligenciados são fontes promissoras de biomoléculas com potencial para aplicação industrial. Este trabalho teve como objetivo a triagem de residuos de peixes descartados (Rachycentron canadum, Caranx crysos, Lutjanus synagris, Scomberomorus mackerel, Parachromis managuensis, Colossoma macropomum, Oreochromis niloticus, Pseudoplatystoma corruscans, Cichla ocellaris, Cynoscion leiarchus) e hidrolisado de camarão (Litopenaeus vannamei) investigando a presença de enzimas colagenolitícas e fibrinoliticas. As atividades colagenolíticas variaram 
de acordo com a espécie, entre 15,95 $\pm 0,07 \mathrm{U} / \mathrm{mg}$ (P. corruscans) e 94,35 \pm 0,02 U/mg (C. ocellaris). Após a classificação por atividade colagenolítica, as espécies selecionadas foram Cichla ocellaris, tendo as propriedades bioquímicas definidas. $O$ pH ideal e a temperatura da atividade colagenolítica foram de 7,5 e $55^{\circ} \mathrm{C}$, respectivamente, mostrando estabilidade na faixa de $\mathrm{pH}$ de 6,5 a 11,5 e temperaturas variando de 25 a $60^{\circ} \mathrm{C}$. A enzima era sensivel a $\mathrm{Cu}^{2+}, \mathrm{Hg}^{2+}$ e $\mathrm{Pb}^{2+}$, sendo parcialmente inibida por PMSF, TLCK e Benzamidina. As atividades fibrinolíticas variaram entre 5,51 $\pm 0,02$ e 56,16 0,42 U/ml, indicando outra possibilidade de reutilização desses subprodutos. Os resultados sugerem vísceras de peixes intestinais como uma fonte promissora de enzimas colagenoliticas e hidrolisado de camarão, bem como fibrinolíticas, ambas apresentando aplicações na indústria farmacêutica e biomédica após os processos de purificação.

Palavras-chave: colágeno, fibrinolítico, peixe.

\section{INTRODUCTION}

World fish production has increased substantially to meet consumer demand. For every $1 \mathrm{~kg}$ of fish, about 60 to $80 \%$ of this biomass is discarded by the fishing industry as devoid of commercial value, leading to environmental pollution from inadequate dumping. This discarded material includes head, tail, fins, scales and internal viscera, and of the latter, deserves attention the digestive ones because they are sources of several biomolecules of industrial interest such as proteins (DABOOR et al., 2012; OLIVEIRA et al., 2017).

The process of obtaining a finished product from the fish byproducts goes through a succession of steps, often at a high cost, from obtaining the residues to the identification of a protein, passing by sequential processes such as isolation and characterization to define features and applicability of the protein (OLIVEIRA et al., 2017). Among these, proteases received notoriety because of their widespread commercial. Studies on the isolation and characterization of proteases from unusual species have demonstrated the enormous potential of these byproducts as sustainable sources. Among the several proteases, the collagenases are gaining importance due their physicochemical properties (DABOOR et al., 2012; OLIVEIRA et al., 2017, DABOOR et al., 2010).

As collagenolytic proteases, they are valuable enzymes for the pharmaceutical and therapeutic industries, assisting in the remodeling of the extracellular matrix, not colorectal cancer (JUCÁ et al., 2008), wound healing, Dupuytren contracture and Peyronie's disease, and can also be applied in veterinary use. In fish processing, it acts on the muscle, helping in the steps of skin removal, collagen extraction and production of bioactive peptides for industrial application (OLIVEIRA et al., 2017, SUPHATHARAPRATEEP et al., 2011; ROCHIMA et al., 2016).

Fibrin accumulation in the blood vessels can lead to thrombosis, hindering blood flow and promoting the development of cardiovascular diseases (AGREBI et al., 2009; UEDA et al., 2007; WANG et al., 2011). Thrombolytic agents have been used extensively in treatment of thrombosis. However, despite its wide use, the common thrombolytic agents have low specificity for fibrin and are costly (WANG et al., 2011) favoring the search for other sources of these enzymes.

Thus, this study aimed to perform a screening and characterization of a collagenolytic enzyme from fish processing residues as well as to investigate/prospect fibrinolytic activity for future research and biomedical applications. This approach may add value to fisheries residues by proposing alternative sources of collagenolytic and fibrinolytic enzymes to the 
market, reducing the industrial processing costs and, at the same time, reducing the environmental impact caused by inadequate dumping of neglected waste.

\section{MATERIAL AND METHODS}

\subsection{Obtaining of waste and preparation of crude extracts}

The enzymatic extraction of the fish species was carried out following the methodology described by Oliveira et al. (2017) and Teruel and Simpson (1995). The preparation of the protein hydrolyzate from the shrimp species was performed following the methodology described by Cahu et al. (2013). The tissue ratio to extraction buffer ( $50 \mathrm{mM}$ Tris-HCl pH 7.5 containing $\left.5 \mathrm{mM} \mathrm{CaCl}_{2}\right)$ was 1:5 (w/v). The intestinal viscera of the species of fish used (50 $\mathrm{g}$ per species) were homogenized by species for 5 minutes at $10,000-12,000 \mathrm{rpm}\left(4^{\circ} \mathrm{C}\right)$ (IKA RW 20D S32, MODELO, China). The homogenate was then centrifuged at 12,000 (x) $\mathrm{g}$ for $30 \mathrm{~min}$ at $4^{\circ} \mathrm{C}$.

The supernatant fraction with the highest total protein, specific and volumetric collagenolytic activities was used as the crude extract (CE) for physicochemical characterization and collagen specificity test. The extract with the highest specific collagenolytic activity $(\mathrm{U} / \mathrm{mg})$ underwent a heating of 30 minutes at $45^{\circ} \mathrm{C}$, for which its biochemical properties were defined. The species selected in the screening had mapped the collagenolytic activity in the stomach, liver, muscle and heart for purposes of comparison with the intestinal enzyme.

\subsection{Collagenolytic assay}

The collagenolytic properties of the crude extract of was determined according of Oliveira et al. (2017), using azocoll as substrate. One enzyme unit (U) was defined as the amount of enzyme required to increase the absorbance in 0.01 at $595 \mathrm{~nm}$. The assays were performed in quadruplicate.

\subsection{Michaelis-Menten kinetics (Km and Vmax)}

The substrates used in the kinetic tests were azocoll with increasing concentrations (1 $20.0 \mathrm{mg} / \mathrm{mL}$ ) in $50 \mathrm{mM}$ Tris- $\mathrm{HCl} \mathrm{pH} 7.5$ buffer at $55^{\circ} \mathrm{C}$ for $30 \mathrm{~min}$ as described in the previous section. The reactions were performed in quadruplicate.

\subsection{Biochemical properties of collagenolytic enzyme}

\subsubsection{Optimum temperature and thermal stability}

The effect of temperature on collagenolytic activity was investigated in various temperatures at $\mathrm{pH}$ 7.5. The enzyme in extraction buffer was assayed for 1 hour in a range from 25 to $90{ }^{\circ} \mathrm{C}$, and the remaining collagenolytic activity was then measured as described above. Control activity represented $100 \%$ and sample activities were expressed in relation to control. The thermal stability was measured in the same way of optimum temperature after incubation of the enzyme in the range from 25 to $90{ }^{\circ} \mathrm{C}$ for 1 hour and after $15 \mathrm{~min}$ equilibration at room temperature (OLIVEIRA et al., 2017).

\subsubsection{Optimum $\mathrm{pH}$ and stability}

These assays were carried out in different $\mathrm{pH}$ using the buffers: $0.5 \mathrm{M}$ citrate-phosphate ( $\mathrm{pH}$ 4.0-7.0), $0.1 \mathrm{M}$ Tris- $\mathrm{HCl}$ (pH 7.5-8.5) and 0.1 M glycine- $\mathrm{NaOH}$ (pH 9.0-12.0), containing $5 \mathrm{mM} \mathrm{CaCl}_{2}$. The reaction mixtures were incubated for 1 hour at $37{ }^{\circ} \mathrm{C}$ and the enzyme activities were measured as described. The influence of $\mathrm{pH}$ on enzyme stability was determined by incubating the enzyme with various buffer solutions, at a ratio of 1:1 for 1 hour at $37^{\circ} \mathrm{C}$ and returning to the optimum $\mathrm{pH}$ (OLIVEIRA et al., 2017). 


\subsubsection{Sensitivity to metal ions and inhibitors}

The effect of metal ions on the enzyme activity was investigated by adding metal ions $\left(\mathrm{K}^{+}, \mathrm{Na}^{+}, \mathrm{Hg}^{2+}, \mathrm{Pb}^{2+}, \mathrm{Cu}^{2+}, \mathrm{Cd}^{2+}, \mathrm{Zn}^{2+}, \mathrm{Ba}^{2+}, \mathrm{Mg}^{2+}, \mathrm{Ca}^{2+}\right.$ and $\left.\mathrm{Al}^{3+}\right)$ to the reaction mixture. The final concentration of each metal ion was $1 \mathrm{mM}$. Each ion was incubated for 1 hour at a ratio of $1: 1$, and then the activity was performed as described before. The sensitivity to inhibitors was performed by incubating the crude extract $(30 \mu \mathrm{l})$ was incubated for 1 hour at $25^{\circ} \mathrm{C}$ with of protease inhibitors $(30 \mu 1,8 \mathrm{mM})$ : phenylmethylsulphonyl fluoride (PMSF); N-p-tosyl-Llysin chloromethyl ketone (TLCK); benzamidine; N-tosyl-L-phenylalaninechloromethyl ketone (TPCK); ethylenediamine tetra-acetic acid (EDTA); and $\beta$-mercaptoethanol. Each ion was incubated for 1 hour at a ratio of 1:1, and then the activity was performed as described above. The results were expressed as percentage of the control activity (OLIVEIRA et al., 2017).

\subsection{Specificity test for type I collagen}

The measure of the digestion of native collagen type I was performed according to the method of Oliveira et al. (2017), Moore and Stein (1954) and Park et al. (24) with a slight modification. The concentration of hydrolyzate-amino acids was determined using a standard curve of L-leucine. One unit (U) of enzyme activity is defined as the amount of enzyme that is required for the hydrolysis of $1 \mathrm{mmol}$ of substrate per $\mathrm{h}$.

\subsection{Total protein dosage}

The protein concentration of all tissue extracts was determined by the method of bicinchoninic acid (BCA) according to Smith et al. (1985).

\subsection{Fibrinolytic assay}

The fibrinolytic activity was determined using the spectrophotometric method (WANG et al., 2011). In this assay, 1 unit (fibrin degradation unit) was defined as the increase of 0.01 in absorbance per minute at $275 \mathrm{~nm}$.

\subsection{Statistical analysis}

All values are presented as mean \pm standard deviations. These data were statistically analyzed by ANOVA, followed by a post hoc (Tukey) test, when indicated. Differences between groups were accepted as significant at $95 \%$ confidence level $(p<0.05)$.

\section{RESULTS AND DISCUSSIONS}

\subsection{Waste screening: collagenolytic enzyme}

Collagenolytic activity varied according to the species of fish tested, and it was detected, in ascending order $(\mathrm{U} / \mathrm{mg})$ : surubim $P$. corruscans $(15.95 \pm 0.07)$, Jaguar cichlid $P$. managuensis (31.98 \pm 0.01$)$, Lane snapper Lutjanus synagris $(35.18 \pm 0.07)$, Mackerel $S$. mackerel (46.88 \pm 0.03$)$, Cobia $R$. canadum (52.13 \pm 0.11$)$, Nile tilapia O. niloticus $(58.27 \pm$ 0.19), tambaqui C. macropomum cecum $(66.68 \pm 0.04)$, Blue runner C. crysos (70.54 \pm 0.09$)$, tambaqui C. macropomum intestine $(73.49 \pm 0.00)$ and peacock bass C. ocellaris $(94.35 \pm$ $0.02)$. The $L$. vannamei hydrolyzate had the lowest collagenolytic activity $(3.29 \pm 00 \mathrm{U} / \mathrm{mg})$ when compared to the enzymes extracted from the gut of the fish species. After screening, the crude intestinal extract of peacock bass $C$. ocellaris had its activity increased by $35.07 \%$ after preheating, to the specific activity of $127.44 \pm 009 \mathrm{U} / \mathrm{mg}$.

For the mapping of the peacock bass $C$. ocellaris species, the collagenolytic activity of 
the stomach $(3.83 \pm 0.003 \mathrm{U} / \mathrm{mg})$, heart $(61.2 \pm 0.007 \mathrm{U} / \mathrm{mg})$, muscle $(12.58 \pm 0.007 \mathrm{U} / \mathrm{mg})$ and liver $(15.44 \pm 0.004 \mathrm{U} / \mathrm{mg})$, results that confirmed the intestine as the residue with the highest collagenolytic activity in this species. Similar results were described by Yoshinaka et al. (1978) when investigating the presence of the collagenolytic enzyme in bluefin tuna Thunnus thynnus, umazurahagi Novodon modestus and shotted halibut Eopsetta grigorjewi $(5.2,66.3$ and $82.8 \mathrm{U} / \mathrm{mg}$ stomach, intestine and pyloric caeca, respectively) and Oliveira et al. (2017) when they investigated in the intestine $(22.0 \pm 0.02 \mathrm{U} / \mathrm{mg})$ and muscle $(9.82 \pm 0.14$ $\mathrm{U} / \mathrm{mg}$ ) of smooth weakfish C. leiarchus. Thus, in this work, the enzymes extracted from the intestine of $C$. ocellaris followed to define their biochemical parameters.

\subsection{Biochemical properties: collagenolytic enzyme}

The Michaelis-Menten constant $(\mathrm{Km})$ for the crude extract of peacock bass $C$. ocellaris was $5.92 \mathrm{mM}$ and Vmax was $294.40 \mathrm{U} / \mathrm{mg}$. No results were found of studies that employ azocoll as substrate in fish species regarding kinetic parameters. The kinetic parameters will provide data about efficacy of the enzyme, making it potentially enhanced in industrial processing (PARK et al., 2002).

The protease recovered from C. ocellaris waste presented biochemical properties similar to those collagenolytic proteases widespread in literature. Such features enable and empower our protease to compete in the commercial market. The optimum temperature of the enzyme activity was $55^{\circ} \mathrm{C}$ with marked reduction above $65^{\circ} \mathrm{C}$ and total loss of activity at $75^{\circ} \mathrm{C}$. The thermal stability was observed between $25^{\circ} \mathrm{C}$ and $60^{\circ} \mathrm{C}$.

The optimum $\mathrm{pH}$ of the enzyme was 7.5 and it was stable in $\mathrm{pH}$ between 6.5 and 11.5. The results are consistent with those found for collagen extracted from waste of subtropical fish such as those described in literature (DABOOR et al., 2012; OLIVEIRA et al., 2017; PARK et al., 2002; BYUN et al., 2002; KIM et al., 2002). The optimum temperature and $\mathrm{pH}$ of the enzymes with collagenolytic properties will depend on the species and the type of tissue under study. Enzyme activity exposed to ions $\mathrm{K}^{+}, \mathrm{Ca}^{2+}, \mathrm{Ba}^{2+}$ and $\mathrm{Mg}^{2+}$ showed no significant difference $(p<0.05)$ compared to the control group $(100 \%)$, differing from the other metal ions with statistically significant data $(\mathrm{p}>0.05)$.

The degree of inhibition for Benzamidine and TLCK was stronger than other inhibitors tested although all presented significant difference $(\mathrm{p}>0.05)$ when compared to control $(100 \%)$. The inhibition of enzyme activity was weaker in presence of EDTA, an inhibitor of metalloproteinases, when compared to PMSF and TLCK, inhibitors of serine proteases, indicating that the enzyme under study is a serine protease. There was also reduced activity when subjected the enzyme to $\beta$-Mercaptoethanol, indicating that the structure of the enzyme presents disulfide bonds. Similar results of inhibition were reported by Oliveira et al. (2017) for collagenolytic enzyme of smooth weakfish C.leiarchus. In this sense, the knowledge of temperature, $\mathrm{pH}$, activators and inhibitors is essential to control the enzyme activity, especially in the industrial processing.

The collagenolytic enzyme extracted from $C$. ocellaris presented ability to cleave collagen type I reaching the highest hydrolysis degree after 48 hours. The collagen cleavage by these proteases showed a marked increase from 36 to $48 \mathrm{~h}$ (Figure 1). Similar results were found by Oliveira et al. (2017) for the smooth weak fish C. leiarchus. This can be explained by the steps of collagen type I enzymatic hydrolysis in which collagenases from the matrix metalloproteinases family have to previously break the triple-helical domain of native structure of this collagen so that it can be degraded to lower molecular weight components by other unspecific collagenases and gelatinases (DABOOR et al., 2010; PARK et al., 2002; KIM et al., 2002; SAITO et al., 2002). 
Figure 1. Peacock bass Cichla ocellaris collagenolytic protease activity towards bovine Achilles tendon collagen type I at different incubation times (12, 24, 36 and 48 hours). Data represented as mean $\pm \mathrm{SD}$. Figures created with MicroCal ${ }^{\circledR}$ Origin ${ }^{\circledR}$ Version 8.0 (MicroCal, Northampton, MA, USA).

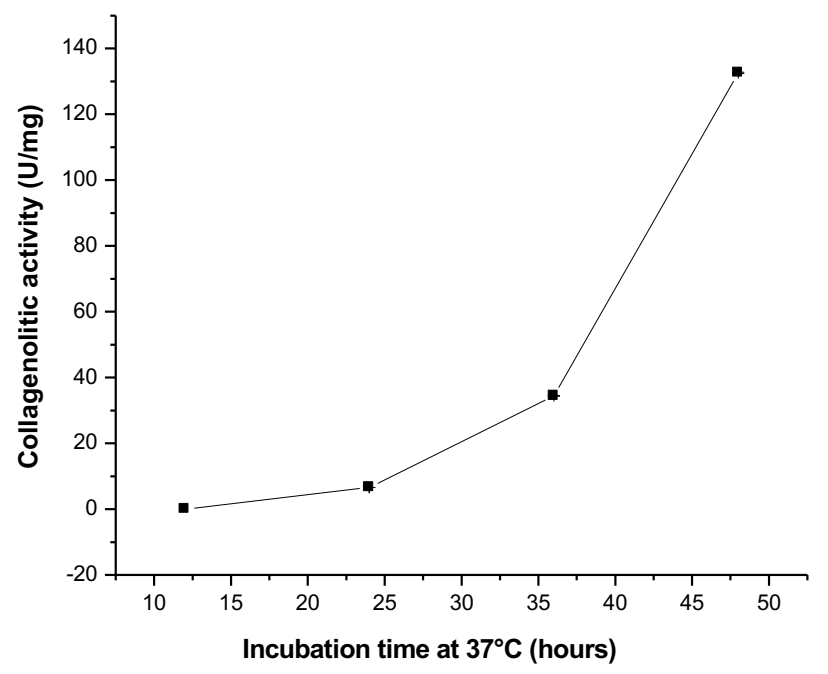

3.3 Waste screening: fibrinolytic enzyme

Here, some the selected fish processing residues used in the initial screening of this study presented ability to cleave fibrin aggregates at several rates $(\mathrm{U} / \mathrm{ml})$ : cobia $R$. canadum (13.29 \pm 0.06$)$, blue runner C. crysos (5.73 \pm 0.01$)$, lane snapper L. synagris $(5.51 \pm 0.02)$, mackerel S. mackerel $(24.12 \pm 0.03)$, jaguar cichlid P. managuensis $(28.55 \pm 0.07)$, tambaqui C. macropomum (35.09 \pm 0.13$)$, surubim $P$. corruscans $(16.93 \pm 0.11)$, smooth weakfish $C$. leiarchus $(22.78 \pm 0.01)$, peacock bass $C$. ocellaris $(22.53 \pm 0.60)$ and gray shrimp hydrolyzate Litopenaeus vannamei $(56.16 \pm 0.42)$. Fish residue has been reported as a source of substrate for the growth of microorganisms producing fibrinolytic enzymes, such as those reported by Zakaria et al (2015) observed that strains of Bacillus cereus presenting fibrinolytic in seafood. To date, no fibrinolytic activity has been reported from shrimp hydrolyzate, making reuse a promising source of research for the delivery of enzymes for therapeutic purposes.

\section{CONCLUSIONS}

Thus, fish species can be used as potential sources of collagenolytic enzymes and the hydrolyzate of shrimp L. vannamei as a source of fibrinolytic, appearing as an alternative source for the pharmaceutical and biomedical industry.

\section{REFERENCES}

DABOOR, S.M.; BUDGE, S.M.; GHALY, A.E.; BROOKS, M.S.; DAVE, D. Isolation and activation of collagenase from fish processing waste. Adv Biosci Biotechnol., 3: 191-203, 2012.

OLIVEIRA, V.M.; ASSIS, C.R.D.; HERCULANO, P.N.; CAVALCANTI, M.T.H.; BEZERRA, R.S.; PORTO, A.L.F. Collagenase from smooth weakfish: extraction, partial 
purification, characterization and collagen specificity test for industrial application. B Inst Pesca, 43: 52-64, 2017.

DABOOR, S.M.; BUDGE, S.M.; GHALY, A.E.; BROOKS, M.S.; DAVE, D. Extraction and Purification of Collagenase Enzymes: A Critical Review. Am J Biochem Biotechnol, 6: 239263, 2010.

JUCÁ, M.; NUNES, B.L.B.B.P.; MENEZES, H.L.; GOMES, E.G.A.; MATOS, D. Metaloproteinases 1 e 7 e câncer colorretal. Rev Bras Coloproct, 28: 353-362, 2008.

SUPHATHARAPRATEEP, W.; CHEIRSILP, B.; JONGJAREONRAK, A. Production and properties of two collagenases from bacteria and their application for collagen extraction. $\mathbf{N}$ Biotechnol; 28: 649-655, 2011.

ROCHIMA, E.; SEKAR, N.; BUWONO, I.D.; AFRIANTO, E.; PRATAMA, R.I. Isolation and characterization of collagenase from Bacillus subtilis (Ehrenberg, 1835); ATCC 6633 for degrading fish skin collagen waste from Cirata Reservoir, Indonesia. Aquat Procedia, 7: 7684, 2016.

AGREBI, R.; HADDAR, A.; HAJJI, M.; FRIKHA, F.; MANNI, L.; JELLOULI, K.; NASRI, M. Fibrinolytic enzymes from a newly isolated marine bacterium Bacillus subtilis A26: characterization and statistical media optimization. Canad J Microbiol, 55: 1049-1061, 2009.

UEDA, M.; KUBO, T.; MIYATAKE, K.; NAKAMURA, T. Purification and characterization of fibrinolytic alkaline protease from Fusarium sp. BLB. Appl Microbiol Biotechnol, 74: 331-338, 2007.

WANG, S.; WU, Y.; LIANG, T. Purification and biochemical characterization of a nattokinase by conversion of shrimp shell with Bacillus subtilis TKU007. New Biotechnol, 28: 196-202, 2011.

TERUEL, S.R.L.; SIMPSON, B.K. Characterization of the collagenolytic enzyme fraction from winter flounder (Pseudopleuronectes americanus). Comp Biochem Physiol B, 112: $131-136,1995$.

CAHU, T.B.; SANTOS, S.D.; MENDES, A.; CÓRDULA, C.R.; CHAVANTE, S.F.; CARVALHO, L.B.; NADER, H.B.; BEZERRA, R.S. Recovery of protein, chitin, carotenoids and glycosaminoglycans from pacific white shrimp (Litopenaeus vannamei) processing waste. Process Biochem, 47: 570-577, 2013.

MOORE S, STEIN W. A modified ninhydrin reagent for the photometric determination of amino acids and related compounds. J Biol Chem,; 211: 907-913, 1954.

PARK, J.P.; LEE, S.H.; BYUN, H.G.; KIM, S.H.; KIM SK. Purification and characterization of a collagenase from the mackerel, Scomber japonicas. J Biochem Mol Biol, 35: 576-582, 2002 .

SMITH, P.K.; KROHN, R.I.; HERMANSON, G.T.; MALLIA, A.K.; GARTNER, F.H.; PROVENZANO, M.D.; FUJIMOTO, E.K.; GOEKE, N.M.; OLSON, B.J.; KLENK, D.C. Measurement of protein using bicinchoninic acid. Anal Biochem, 150: 76-85, 1985. 
YOSHINAKA, R.; SATO, M.; IKEDA, S. Distribution of collagenase in the digestive organs of some teleosts. Bull Japan Soc Sci Fish, 44: 263-267, 1978.

BYUN, H.G.; PARK, P.J.; SUNG, N.J.; KIM, S.K. Purification and characterization of a serine proteinase from the tuna pyloric caeca. J Food Biochem, 26: 479-494, 2002.

KIM, S.K.; PARK, P.J.; KIM, J.B.; SHAHIDI, F. Purification and characterization of a collagenolytic protease from the filefish, Novoden modestrus. J Biochem Mol Biol, 335: 165$171,2002$.

SAITO, M.; KUNISAKI, N.; KIMURA, S. Fish collagenase. Fisheries Sci, 68: 1567-1570, 2002.

ZAKARIA, Z.; SALLEH, M.M.; RASHID, N.A.A. Screening and Identification of Fibrinolytic Bacteria from Malaysian Fermented Seafood Products. J Appl Pharm Sci, 10: 022-031, 2015.

\section{ACKNOWLEDGEMENTS}

This work was supported by the Foundation for Research Support of the State of Pernambuco (FACEPE) (Grant number: BFP-0115-5.05/14). 